\title{
Erratum: Ichthyofauna marine of the Island of Santa Catarina, Southern Brazil: checklist with comments on the species
}

In the article "Ichthyofauna marine of the Island of Santa Catarina, Southern Brazil: checklist with comments on the species" with the DOI code number http://dx.doi.org/10.1590/1676-0611-BN-2018-0684, published at Biota Neotropica 19(3): e20180684, the title should be

Marine ichthyofauna of Santa Catarina Island, Southern Brazil: checklist with comments on the species

Instead of:

Ichthyofauna marine of the Island of Santa Catarina, Southern Brazil: checklist with comments on the species 